\title{
PEMBELAJARAN BERBASIS PROYEK MENGGUNAKAN SENAM TRANSFORMASI DAN TETRIS GEOGEBRA UNTUK MENINGKATKAN KEMAMPUAN BERPIKIR KREATIF SISWA
}

\author{
Muhammad Abror \\ SMPN 1 Unter Iwes, Sumbawa; muh.abror@gmail.com
}

\begin{abstract}
Abstrak. Kemampuan berpikir kreatif merupakan kemampuan yang penting dalam matematika untuk menghadapi tuntutan abad ke-21. Salah satu model pembelajaran yang dapat meningkatkan kemampuan berpikir kreatif matematis siswa adalah Pembelajaran Berbasis Proyek. Penelitian ini bertujuan untuk mengetahui peningkatan kemampuan berpikir kreatif matematis siswa melalui Pembelajaran Berbasis Proyek menggunakan Senam Transformasi dan Tetris GeoGebra. Instrumen penelitian berupa tes berbentuk uraian, terdiri atas tes awal dan tes akhir yang mengukur kemampuan berpikir kreatif matematis siswa meliputi kemampuan kelancaran, keluwesan, keaslian, dan keterincian. Selanjutnya dilakukan analisis data meliputi uji normalitas, homogenitas, dan uji t-tes dengan menggunakan bantuan aplikasi SPSS. Dari penelitian, didapat hasil bahwa ada peningkatan nilai yang signifikan terhadap kemampuan berpikir kreatif matematis siswa, baik pada kelas dengan Pembelajaran Berbasis Proyek menggunakan Senam Transformasi maupun pada kelas dengan Pembelajaran Berbasis Proyek menggunakan Tetris GeoGebra. Tidak ada perbedaan yang signifikan antara rata-rata tes akhir pada kedua kelas tersebut. Dengan demikian, kedua tugas proyek yang dipakai dalam Pembelajaran Berbasis Proyek ini dapat digunakan dalam pembelajaran materi Transformasi.
\end{abstract}

Kata Kunci: Pembelajaran Berbasis Proyek, Senam Transformasi, Tetris GeoGebra, Kemampuan berpikir kreatif

\section{PROJECT BASED LEARNING USING TRANSFORMATION GYMNASTICS AND TETRIS GEOGEBRA TO IMPROVE STUDENT'S CREATIVE THINKING ABILITY}

\begin{abstract}
The ability to think creatively is an important ability in mathematics to deal with the demands of the 21st century. One learning model that can improve students' mathematical creative thinking skills is Project Based Learning. This study aims to determine the improvement of students' mathematical creative thinking abilities through Project Based Learning using Transformation Gymnastics and Tetris GeoGebra. Research instruments used in this study is a test in the form of description, consisting of pretest and posttest that measures the ability of mathematical creative thinking including fluency, flexibility, originality, and elaboration. Data analysis includes tests of normality, homogeneity, and t-test using SPSS application assistance. The results
\end{abstract}


showed that there was a significant increase in the value of students' creative thinking abilities, both in classrooms with Project Based Learning using Transformation Gymnastics and in classrooms with Project Based Learning using Tetris GeoGebra. There was no significant difference between the average posttest in the two classes. Thus, the two project tasks used in this Project Based Learning can be used in learning Transformation material.

Keywords: Project Based Learning; Transformation Gymnastics; Tetris GeoGebra; Creative thinking ability

\section{Pendahuluan}

Kemampuan berpikir kreatif merupakan salah satu kemampuan yang penting dalam matematika. Kemampuan berpikir kreatif merupakan salah satu kemampuan berpikir yang menjadi tuntutan abad ke-21 sebagaimana disebutkan dalam Partnership for 21st Century Skills (P21) yaitu communication, collaboration, critical thinking, dan creativity, yang disingkat 4Cs (Bialik \& Fadel, 2015). Hal ini juga sejalan dengan salah satu tujuan pembelajaran matematika di Indonesia untuk mempersiapkan siswa memiliki kemampuan hidup sebagai pribadi dan warga negara yang kreatif (Kemendikbud, 2013).

Kemampuan berpikir kreatif dalam matematika atau berpikir kreatif matematis merupakan tingkat kemampuan berpikir siswa untuk menemukan sebanyak-banyaknya jawaban atas suatu masalah dengan cara beragam dan relevan secara lancar, asli, dan terperinci berdasarkan data yang tersedia (Susanto, 2013: 105). Dengan demikian kemampuan berpikir kreatif siswa dapat dilihat dari keterampilan berpikir lancar, berpikir luwes (fleksibel), berpikir orisinal, dan berpikir terperinci (elaborasi) (Munandar, 2014: 192). Dengan berpikir kreatif diharapkan siswa dapat menyelesaikan masalah atau soal dengan berbagai ide atau gagasan yang luas.

Kenyataan di lapangan, dari hasil analisis ulangan siswa yang dilakukan guru/penulis selama ini, jarang sekali ada siswa yang menjawab soal dengan cara berbeda dari yang pernah dicontohkan guru. Siswa menyelesaikan permasalahan hanya dengan satu cara penyelesaian, yaitu dengan rumus. Hal ini disebabkan guru terbiasa memberikan soal-soal yang hanya memiliki jawaban atau cara tunggal dalam penyelesaiannya dan kurang memperhatikan kemampuan berpikir kreatif dalam pembelajaran matematika (Saefudin, 2014). Soal seperti ini tidak mendorong siswa berpikir kreatif, melainkan hanya menerapkan algoritma yang sudah diketahui (Siswono, et.al, 2013).

Hal ini diperkuat dari hasil tes awal pada siswa kelas IX.1 dan IX.2 SMP Negeri 1 Unter Iwes yang menunjukkan kemampuan berpikir kreatif matematis siswa rendah. Dari hasil tes awal diperoleh nilai rata-rata sebesar 42,18; dengan 55\% siswa dalam kategori cukup kreatif, $42 \%$ kategori kurang kreatif, dan 3\% dengan kategori sangat tidak kreatif.

Untuk mendorong siswa berpikir kreatif, perlu diciptakan lingkungan dan atau proses pembelajaran yang dapat mengembangkan kemampuan berpikir kreatif siswa (Sudarma, 2013). Salah satu model pembelajaran yang dapat meningkatkan kemampuan berpikir kreatif matematis siswa adalah Pembelajaran Berbasis Proyek. Hal ini diungkapkan Anita (2017) 
bahwa Pembelajaran Berbasis Proyek dapat menumbuhkan kemampuan berpikir kreatif matematis.

Warsono dan Hariyanto (2012: 153) menyatakan Pembelajaran Berbasis Proyek sebagai suatu pengajaran yang mengaitkan teknologi dengan masalah kehidupan sehari-hari atau dengan suatu proyek di sekolah. Dalam Pembelajaran Berbasis Proyek, siswa dituntut untuk berpikir kritis menyelesaikan masalah dengan cara menganalisis, berargumen, mengevaluasi, menentukan langkah apa yang harus diambil, menyimpulkan dan memunculkan wawasan terhadap tiap-tiap permasalahan melalui kerja sama dan komunikasi antar peserta didik (Dirjen Dikdasmen, 2016). Penerapan model Pembelajaran Berbasis Proyek menuntut siswa menyelesaikan suatu proyek dalam kehidupan sehari-hari.

Proyek yang diberikan kepada siswa dapat berkaitan dengan penggunaan teknologi seperti permainan menggunakan Tetris Geogebra atau berkaitan dengan bidang lainnya seperti proyek pembuatan Senam Transformasi.

Tetris Geogebra adalah suatu permainan Tetris yang dibuat pada perangkat lunak GeoGebra bertujuan memanipulasi tetromino dengan cara memutar dan menggeser kesamping menggunakan konsep transformasi berupa rotasi dan translasi sehingga akan terbentuk garis horizontal tanpa celah yang menutup permukaan layar. Gerakan tetromino pada tetris menggambarkan suatu transformasi yaitu rotasi dan translasi.

Dalam permainan Tetris Geogebra menampilkan empat hasil perputaran tetromino, yang merupakan hasil perputaran dengan besar sudut $-90^{\circ}, 0^{\circ}, 90^{\circ}$, dan $180^{\circ}$. Ini bisa diartikan sebagai rotasi objek dengan sudut putar tersebut didalam konsep transformasi matematika. Sedangkan gerakan kesamping dan kebawah dari tetromino dapat diartikan sebagai suatu translasi objek sejauh $\mathrm{x}$ satuan kekiri atau kekanan dan y satuan kebawah atau keatas yang dipelajari siswa pada materi Transformasi.

Senam Transformasi adalah gabungan gerakan-gerakan yang dipilih dan diciptakan dengan berencana, serta disusun secara sistematis oleh siswa sendiri, dimana gerakan-gerakannya melukiskan gerakan transformasi yang melibatkan refleksi, rotasi, dan translasi. Proses pelaksanaan kegiatan pembelajaran melalui tahapan pemanasan, eksplorasi, komposisi, presentasi, dan refleksi.

Kegiatan dalam proyek Senam Transformasi didukung dengan alat bantu peraga berupa dadu transformasi, lembar infografis transformasi, dan lembar gerakan tubuh. Dadu transformasi berbentuk dadu yang bagian sisi-sisinya diberi gambar yang menjelaskan pengertian gerakan transformasi. Lembar Infografis Transformasi berupa lembaran yang berisi gambar representasi dari model transformasi, masing-masing tiga mewakili pencerminan, pergeseran dan perputaran, berupa kata-kata, definisi, gambar bentuk buatan manusia bentuk struktural di alam. Lembar gerakan tubuh ini berisi gambar gerakan dari bagian tubuh berupa gerakan kepala, tangan, dan kaki.

Tujuan penelitian ini adalah untuk mengetahui: (1) Peningkatan kemampuan berpikir kreatif matematis siswa dengan Pembelajaran Berbasis Proyek menggunakan Senam Transformasi, (2) Peningkatan kemampuan berpikir kreatif matematis siswa dengan Pembelajaran Berbasis 
Proyek menggunakan Tetris GeoGebra, (3) Perbedaan peningkatan kemampuan berpikir kreatif matematis siswa antara Pembelajaran Berbasis Proyek menggunakan Senam Transformasi dengan Pembelajaran Berbasis Proyek menggunakan Tetris GeoGebra.

\section{Metode}

Penelitian ini merupakan penelitian quasi experiment dengan pretes and posttes Nonequivalent Group Design. Penelitian ini dilakukan pada dua kelas, yaitu kelas IX.1 dan kelas IX.2 di SMP Negeri 1 Unter Iwes Tahun Pelajaran 2018/2019 pada bulan Januari sampai Maret 2019. Kelas IX.1 dan IX.2 masing-masing berjumlah 32 siswa. Pada Kelas IX.1 diberi perlakuan dengan Pembelajaran Berbasis Proyek menggunakan Senam Transformasi (PBPST), sedangkan kelas IX.2 dengan Pembelajaran Berbasis Proyek menggunakan Tetris GeoGebra (PBPTG). Sebelum dan sesudah perlakuan diberikan tes pada kedua kelas.

Instrumen penelitian berupa tes yang mengukur kemampuan berpikir kreatif matematis siswa. Tes ini berbentuk soal uraian yang terdiri dari 5 butir soal mengenai materi Transformasi dengan skor tiap butir soal antara 0 sampai 4. Indikator yang diuji dalam soal terkait aspek kemampuan kelancaran (fluency), keluwesan (fleksibility), keaslian (originality), dan keterincian (elaboration).

Ada 2 tes yang dibuat, yaitu tes awal yang mengukur kemampuan awal siswa dan tes akhir yang mengukur kemampuan siswa setelah diberikan PBPST atau PBPTG. Tes awal diberikan setelah siswa menerima materi transformasi tapi belum dilakukan Pembelajaran Berbasis Proyek.

Dari hasil tes awal dan tes akhir yang diperoleh dari kedua kelas, kemudian dilakukan analisis data terkait uji normalitas, uji homogenitas, dan uji t-tes. Analisis dilakukan dengan bantuan software SPSS dengan menggunakan tingkat signifikan 5\%.

Uji normalitas menggunakan Kolmogorov-Smirnov yang dalam perhitungan menggunakan program SPSS untuk menguji apakah semua variabel berdistribusi normal atau tidak. Dari hasil uji normalitas diperoleh nilai signifikansi (sig) untuk tes awal PBPST sebesar 0,13 dan tes akhir sebesar 0,10; sedangkan untuk tes awal kelas PBPTG sebesar 0,06 dan 0,09 untuk tes akhir. Data ini memperlihatkan bahwa semua kelompok data memiliki nilai signifikansi (sig) yang lebih besar dari 0,05 sehingga dapat disimpulkan kelompok data tersebut berdistribusi normal.

Uji homogenitas menggunakan levene's Test for equality of Variance untuk mengetahui tingkat kesamaan varians antara dua kelompok yaitu kelas PBPST dan kelas PBPTG. Dari hasil uji homogenitas diperoleh nilai signifikansi (sig) based on mean dari tes awal sebesar 0,32 dan untuk tes akhir sebesar 0,15. Ini menunjukkan bahwa data tes awal dan tes akhir memiliki nilai signifikansi (sig) yang lebih besar dari 0,05, sehingga dapat disimpulkan kelompok data tersebut homogen.

Uji paired-Sample t-test dilakukan terhadap tes awal dan tes akhir kelas PBPST dan kelas PBPTG untuk mengetahui peningkatan skor berdasarkan rata-rata tes awal dan rata-rata tes 
akhir. Analisis independent-Sample t-test terhadap tes akhir kelas PBPST dan tes akhir kelas PBPTG bertujuan untuk mengetahui ada tidaknya perbedaan yang signifikan nilai tes akhir pada kelas PBPST dan kelas PBPTG. Dilakukan pula uji t kenaikan skor nilai kelas PBPST dan kelas PBPTG untuk mengetahui ada tidaknya perbedaan kenaikan nilai tes kemampuan berpikir kreatif matematis pada kelas PBPTT dan kelas PBPTG, serta untuk mengetahui mana yang memiliki kenaikan yang lebih tinggi.

\section{Hasil dan Pembahasan}

\subsection{PBPST untuk meningkatkan kemampuan berpikir kreatif matematis siswa}

Senam Transformasi dirancang untuk memperkenalkan siswa pada materi translasi, rotasi, dan refleksi melalui eksplorasi yang diwujudkan dalam komposisi gerakan senam. Senam Transformasi ini bukan dibuat oleh guru, tapi dirancang sendiri oleh siswa berdasarkan kreativitas mereka yang merupakan tugas proyek dalam pembelajaran ini.

Tahapan Pembelajaran Proyek menggunakan Senam Transformasi dijelaskan berikut.

a) Penentuan proyek

Guru menyampaikan pertanyaan yang mengeksplorasi pengetahuan siswa terkait tugas yang akan diselesaikan siswa. Produk yang dihasilkan berupa karya Senam Transformasi.

b) Perancangan langkah-langkah penyelesaian proyek

Siswa mencari gambar-gambar gerakan senam yang mencerminkan gerakan transformasi dari beberapa sumber, bisa dari internet maupun buku.

c) Penyusunan jadwal pelaksanaan proyek

Siswa menyusun jadwal penyelesaian proyek bersama guru. Disepakati proyek diselesaikan dalam 2 kali pertemuan.

d) Penyelesaian proyek dengan fasilitas dan monitoring guru

Siswa membuat alat bantu presentasi senam dari bahan yang sudah dikumpulkan. Alat bantu peraga berupa dadu transformasi, lembar infografis transformasi, dan lembar gerakan tubuh. Setiap siswa mendapat giliran untuk menciptakan dan melakukan gerakan, kemudian diminta membuat gerakan transformasinya. Setiap anggota kelompok melakukan undian dengan dadu transformasi untuk menentukan apakah gerakan yang mereka buat mengandung unsur translasi, refleksi, atau rotasi. Setelah itu, gerakan tersebut diajarkan pada anggota kelompoknya. Setiap kelompok kemudian mengurutkan gerakan yang mereka buat menjadi satu urutan gerakan gabungan. Siswa harus mempertimbangkan urutan gerakan itu dengan baik sehingga dapat membantu mereka beralih dari satu gerakan ke gerakan berikutnya dengan lancar. Selama kegiatan berlangsung, guru memantau kegiatan ditiap kelompok.

e) Penyusunan laporan dan presentasi hasil proyek 
Tahap ini melibatkan siswa dalam pertunjukan senam mereka. Setiap kelompok mempresentasikan senam yang mereka hasilkan dihadapan kelompok lain. Kelompok bertanggung jawab untuk menjelaskan caranya mereka menerapkan transformasi dalam gerakan senam mereka dan mengurutkannya sehingga tercipta komposisi yang baik.

f) Evaluasi proses dan hasil proyek

Siswa membuat catatan jurnal tentang definisi refleksi, rotasi, dan translasi; mendeskripsikan apa yang mereka pelajari dan yang belum mereka tahu; kontribusi yang mereka buat untuk kelompok mereka; dan menulis tentang tantangan yang mereka hadapi selama Senam Transformasi

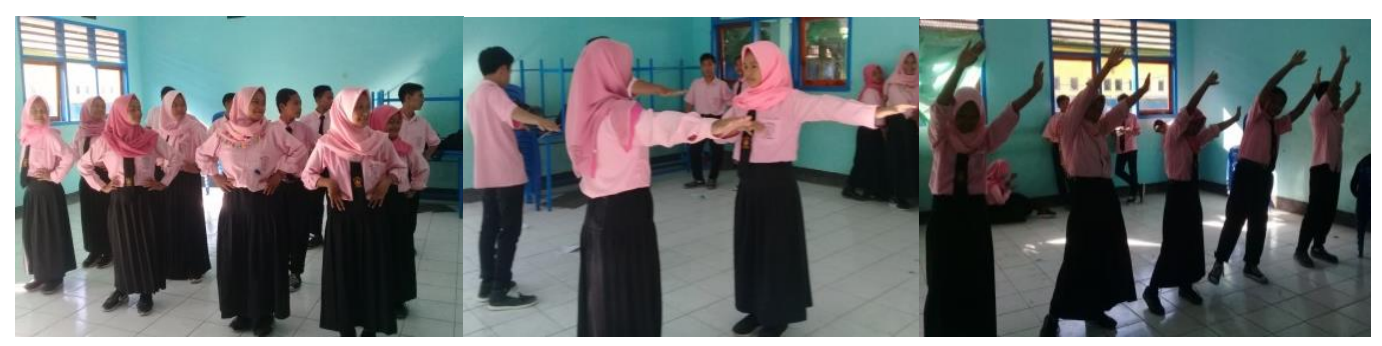

Gambar 1. Senam Transformasi

Untuk mengetahui adanya peningkatan kemampuan kreatif matematis dengan model pembelajaran ini dilakukan analisis terhadap nilai tes awal dan tes akhir di kelas ini. Analisis menggunakan uji paired-Sample t-test terhadap tes awal dan tes akhir dengan bantuan aplikasi SPSS. Hasil Uji paired-Sample t-test kelas PBPST terlihat pada tabel berikut.

Tabel 1. Hasil uji paired-Sample t-test kelas PBPST

\begin{tabular}{|c|c|c|}
\hline Kelas & Rata-rata & sig.(2-tailed) \\
\hline Tes awal PBPST & 42,66 & \multirow{2}{*}{0,000} \\
\cline { 1 - 2 } Tes akhir PBPST & 72,66 & \\
\hline
\end{tabular}

Tabel 1 memperlihatkan adanya peningkatan skor pada kelas PBPST sebesar 30 dengan nilai sig.(2-tailed) sebesar 0,00 lebih kecil dari 0,05 yang berarti dapat disimpulkan terdapat peningkatan secara signifikan pada nilai tes akhir siswa kelas PBPST.

Peningkatan nilai pada kelas PBPST ini menunjukkan bahwa PBPST dapat meningkatkan kemampuan berpikir kreatif matematis siswa. Peningkatan kemampuan berpikir kreatif ini disebabkan karena aktivitas-aktivitas yang dilakukan siswa pada PBPST memberi kesempatan untuk mengembangkan kreativitas siswa. Aktivitas-aktivitas itu meliputi: (1) memilih dan merancang gerakan-gerakan senam, (2) membuat suatu gerakan senam dengan cara menggabungkan gerakan anggota tubuh menjadi suatu gerakan seluruh tubuh yang terdiri dari gerakan kepala, tangan, dan kaki, yang dipilih dari lembar gerakan tubuh, dan (3) menyusun urutan gerakan senam sehingga dapat dilakukan dengan lancar.

Hal ini sesuai dengan hasil beberapa penelitian yang menunjukkan bahwa mewujudkan konsep matematika melalui gerakan dapat mendukung peningkatan kemampuan spasial siswa, komunikasi, kolaborasi, pemikiran kritis, kreatif, dan keterampilan pemecahan 
masalah, diantaranya dapat dilakukan melalui tarian, senam atau yang lainnya (Alibali et.al, 2012).

\subsection{PBPTG untuk meningkatkan kemampuan berpikir kreatif matematis siswa}

Tetris GeoGebra ini sebagai penerapan konsep Transformasi dilakukan satu kali pertemuan selama 3 jam pelajaran yang dilaksanakan pada pertemuan terakhir. Pada pertemuanpertemuan sebelumnya siswa sudah diperkenalkan dengan GeoGebra, yaitu melakukan translasi, rotasi, refleksi, dan dilatasi obyek pada grafik GeoGebra, sehingga siswa sudah tidak asing dengan perangkat lunak ini

Tahapan Pembelajaran Proyek menggunakan Tetris Geogebra ini bisa dilihat dalam tabel berikut.

a) Penentuan proyek

Guru menyampaikan pertanyaan yang mengeksplorasi pengetahuan siswa terkait tugas yang akan diselesaikan siswa. Setiap siswa mendapat tugas yang sama yaitu bermain game Tetris GeoGebra dan menulis langkah-langkah yang dilakukan dalam tabel.

b) Perancangan langkah-langkah penyelesaian proyek

Siswa mencari informasi mengenai tetris dan cara bermain tetris dari beberapa sumber, bisa dari internet maupun buku.

c) Penyusunan jadwal pelaksanaan proyek

Siswa menyusun jadwal penyelesaian proyek bersama guru. Pelaksanaan proyek dilakukan dalam 1 kali pertemuan.

d) Penyelesaian proyek dengan fasilitas dan monitoring guru

Siswa memulai kegiatan proyek dengan bermain Tetris GeoGebra. Setiap menyelesaikan satu bentuk tetromino, siswa menulis bentuk rotasi dan translasinya dalam tabel. Guru memonitoring aktivitas siswa selama menyelesaikan proyek dengan cara melakukan bimbingan kepada siswa yang kesulitan dalam menyelesaikan proyek.

e) Penyusunan laporan dan presentasi hasil proyek

Siswa menyusun laporan hasil proyek berupa hasil pengisian tabel dan gambar akhir hasil permainan tetris yang dilakukan

f) Evaluasi proses dan hasil proyek

Siswa melakukan refleksi terhadap aktivitas dan hasil proyek yang sudah dijalankan 


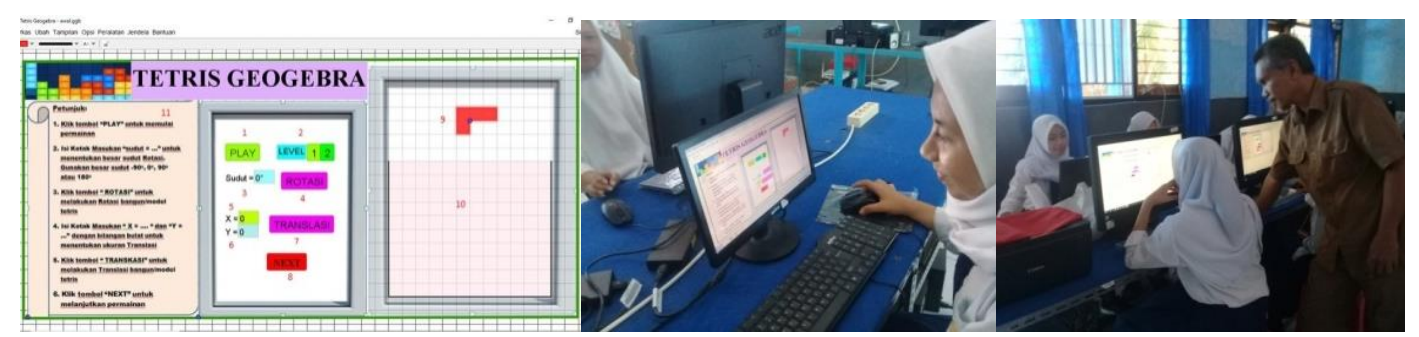

Gambar 2. Tetris GeoGebra

Analisis paired-Sample t-test terhadap tes awal dan tes akhir di kelas PBPTG digunakan untuk melihat ada tidaknya peningkatan nilai pada kelas PBPTG. Hasil uji paired-Sample ttest sebagai berikut.

Tabel 2. Hasil uji paired-Sample t-test kelas PBPTG

\begin{tabular}{|l|l|c|}
\hline Kelas & Rata-rata & sig.(2-tailed) \\
\hline Tes awal PBPTG & 41,72 & \multirow{2}{*}{0,000} \\
\cline { 1 - 2 } Tes akhir PBPTG & 74,06 & \\
\hline
\end{tabular}

Berdasarkan Tabel 2 terlihat ada peningkatan nilai rata-rata sebesar 32,34. Didapatkan juga nilai sig.(2-tailed) sebesar 0,00 lebih kecil dari 0,05 yang berarti dapat disimpulkan terdapat peningkatan secara signifikan pada nilai tes akhir siswa kelas PBPTG.

Peningkatan nilai pada kelas PBPTG ini menunjukkan bahwa PBPTG juga dapat meningkatkan kemampuan berpikir kreatif matematis siswa. Peningkatan kemampuan berpikir kreatif ini disebabkan karena aktivitas-aktivitas siswa pada PBPTG seperti: (1) memilih dua transformasi berurutan (rotasi dan translasi) yang benar sehingga dapat menempatkan tetromino pada koordinat yang diinginkan, dan (2) merancang bentuk tampilan tetromino pada layar.

Penggunaan GeoGebra dalam pembelajaran geometri transformasi ini dapat meningkatkan hasil belajar siswa. Penelitian sihwidi (2016) juga menyimpulkan bahwa dengan bantuan perangkat lunak GeoGebra dalam pembelajaran transformasi geometri dapat meningkatkan aktifitas belajar dan meningkatkan penguasaan kompetensi transformasi geometri.

\subsection{Perbandingan PBPST dengan PBPTG dalam meningkatkan kemampuan berpikir kreatif matematis siswa}

Untuk mengetahui ada tidaknya perbedaan yang signifikan antara nilai tes akhir kelas PBPST dengan kelas PBPTG dilakukan dengan menggunakan uji independent-Sample t-test. Hasil uji t-tes ini ditunjukkan dalam tabel berikut.

Tabel 3. Hasil uji independent-Sample t-test terhadap tes akhir

\begin{tabular}{|l|l|l|c|}
\hline Kelas & Rata-rata & sig. & $\begin{array}{l}\text { sig. (2-tailed) equal } \\
\text { varience assumed }\end{array}$ \\
\hline PBPTT & 72,66 & \multirow{2}{*}{0,152} & 0,565 \\
\hline PBPTG & 74,06 & & \multicolumn{2}{|c|}{0,565} \\
\hline
\end{tabular}


Dari tabel terlihat nilai rata-rata atau mean untuk kelas PBPST adalah 72,66; sedangkan untuk kelas PBPTG sebesar 74,06. Dari hasil nilai signifikasi (sig.) yang diperoleh sebesar $0,152>0,05$; maka dapat dikatakan varian data antara kelas PBPST dengan kelas PBPTG adalah homogen. Kenaikan nilai rata-rata pada kelas PBPST sebesar 30 dan pada kelas PBPTG sebesar 32,34. Jadi kenaikan nilai rata-rata pada kelas PBPTG lebih tinggi dari PBPST. Selanjutnya dari nilai sig. (2-tailed) equal varience assumed sebesar 0,565 0,05 menunjukkan bahwa tidak ada perbedaan yang signifikan antara rata-rata tes akhir pada kelas PBPTT dengan kelas PBPTG.

Penelitian ini menunjukkan bahwa Pembelajaran Berbasis Proyek dapat meningkatkan kemampuan berpikir kreatif matematis siswa. Hal senada diungkapkan dalam penelitian Noviana (2017) dan Lestari (2018) yang menyimpulkan ada pengaruh penerapan model Pembelajaran Berbasis Proyek terhadap peningkatan kemampuan berpikir kreatif matematis siswa.

\section{Kesimpulan dan Saran}

\subsection{Kesimpulan}

Pembelajaran Berbasis Proyek menggunakan Senam Transformasi dapat meningkatkan kemampuan berpikir kreatif matematis siswa. Hal ini ditunjukkan dengan adanya peningkatan nilai rata-rata dari tes awal sebesar 42,66 menjadi 72,66 pada tes akhir.

Pembelajaran Berbasis Proyek menggunakan Tetris GeoGebra dapat meningkatkan kemampuan berpikir kreatif matematis siswa, terlihat dari peningkatan nilai rata-rata dari tes awal sebesar 41,72 menjadi 74,06 pada tes akhir.

Tidak terdapat perbedaan yang signifikan dalam peningkatan kemampuan berpikir kreatif matematis siswa antara Pembelajaran Berbasis Proyek menggunakan Senam Transformasi dengan Pembelajaran Berbasis Proyek menggunakan Tetris GeoGebra..

\subsection{Saran}

Perlu penelitian lanjutan untuk mengembangkan Tetris GeoGebra pada mobile technology android agar siswa bisa memainkan game ini di rumah. Penelitian lanjutan juga diperlukan dalam sampel yang lebih besar sebagai bentuk desiminasi hasil pengembangan untuk mendapat hasil penelitian dengan tingkat generalitas yang lebih tinggi. Faktor kemampuan teknologi siswa juga menjadi faktor penting dalam pelaksanaan proyek, disamping sarana dan prasarana sekolah.

\section{Daftar Pustaka}

Alibali, Martha W., and Nathan, M.J. 2012. Embodiment in Mathematics Teaching and Learning: Evidence from Learners' and Teachers' Gestures. Journal of the Learning Sciences, 21 (2), 24786.

Anita, I. W. 2017. Implementasi Pembelajaran Berbasis Proyek untuk Menumbuhkan Kemampuan Berpikir Kreatif Matematis Mahasiswa. Jurnal Penelitian dan Pembelajaran Matematika (JPPM), 10(1), 125-131. 
Bialik, M., and Fadel, C. 2015. Skills for the 21st Century: What Should Students Learn? Center for Curriculum Redesign Boston, Massachusetts.

Dirjen Dikdasmen. 2016. Panduan Pembelajaran untuk Sekolah Menengah Pertama. Jakarta: Kementerian Pendidikan dan Kebudayaan.

Kemendikbud. 2013. Permendikbud Nomor 65 Tahun 2013 tentang standar proses pendidikan dasar dan menengah. Jakarta: Kementrian Pendidikan dan Kebudayaan.

Lestari, D. F. 2018. Pengaruh Model Pembelajaran Project Based Learning terhadap kemampuan berpikir kreatif siswa Kelas IV. Jurnal Pendidikan Guru Sekolah Dasar, Edisi 17 Tahun ke-7, 1609-1617.

Munandar, U. 2014. Pengembangan Kreativitas Anak Berbakat. Jakarta: Rineka Cipta.

Noviana, H. 2017. Pengaruh Project Based Learning terhadap kemampuan berpikir kreatif matematika siswa. Jurnal Edumath, 3(2), 110-117.

Saefudin, A. A. 2014. Pengembangan kemampuan berpikir kreatif siswa dalam pembelajaran matematika dengan pendekatan pendidikan matematika realistik Indonesia. Al-Bidayah, 4(1), 37-48.

Siswono, T. Y. E., Rosyidi, A. H., Astuti, Y. P., \& Kurniasari, I. 2013. Pemberdayaan guru dalam pembelajaran matematika untuk meningkatkan kemampuan berpikir kreatif siswa SD. Jurnal Ilmu Pendidikan, 18(2), 210-219.

Sihwidi, J. 2016. Penggunaan GeoGebra Untuk Meningkatkan Aktifitas dan Penguasaan Kompetensi Transformasi Geometri di SMKN 1 Tulang Bawang Tengah. Indonesian Digital Journal of Mathematics and Education, 3(4), 208-220.

Sudarma, M. 2013. Mengembangkan Keterampilan Berpikir Kreatif. Jakarta: Raja Grafindo Persada.

Susanto, A. 2013. Teori Belajar \& Pembelajaran di Sekolah Dasar. Jakarta: Kencana.

Warsono dan Hariyanto. 2012. Pembelajaran Aktif Teori dan Asesmen. Surabaya: PT Remaja Rosdakarya. 